\title{
EVALUASI FASILITAS BAGI PENYANDANG DISABILITAS DI STASIUN YOGYAKARTA
}

\author{
Aisyah Nur Jannah ${ }^{1, *)}$, Prayogo Afang Prayitno ${ }^{2}$ and Prima Juanita Romadhona ${ }^{3}$ \\ 1,*)Jurusan Teknik Sipil, Fakultas Teknik Sipil dan Perencanaan, Universitas Islam Indonesia \\ Email: aisyah.nur.jannah@uii.ac.id \\ ${ }^{2}$ Jurusan Teknik Sipil, Fakultas Teknik Sipil dan Perencanaan, Universitas Islam Indonesia \\ Email: prayogo.afang.prayitno@uii.ac.id \\ ${ }^{3}$ Jurusan Teknik Sipil, Fakultas Teknik Sipil dan Perencanaan, Universitas Islam Indonesia \\ Email: prima_dhona@uii.ac.id
}

\begin{abstract}
Yogyakarta Station is a railway station located in Yogyakarta City. As a transportation mode transfer point, the station must be inclusive for all train passengers, including passengers with disabilities. An inclusive railway station will be accomplished by providing station facilities that accommodate accessibility for passengers with disabilities. This study aims to evaluate the facilities for passengers with disabilities at Yogyakarta Station. By understanding the evaluation, railway operators and governments will create specific improvements that would make the station more inclusive. The facilities are following the Minister of Transportation Regulation Number PM 98 of 2017 concerning Providing Accessibility to Public Transportation Services for Service Users with Special Needs. This study uses the IPA (Importance Performance Analysis) method obtained through observation and questionnaires. The result shows that based on 15 (fifteen) facilities evaluated, all facilities are available in Yogyakarta Station except the guide block to the counters and toilets, information in Braille letters, ticketing counters/special ticketing counters, and information/customer service rooms which accessible easily. In addition, based on the IPA method, improving facilities for passengers with disabilities at Yogyakarta Station should be prioritized for ready-to-use wheelchair facilities, access to and from passengers in multi-story buildings, and toilet access.
\end{abstract}

Keywords: Disabilities, facilities, railway station, Importance Performance Analysis.

\section{PENDAHULUAN}

Kota Yogyakarta sebagai kota pelajar, kota wisata, dan juga kota budaya telah menarik masyarakat domestik maupun wisatawan mancanegara untuk mengunjungi atau tinggal sementara di wilayah Yogyakarta. Berdasarkan data Badan Pusat Statistk (2020), sepanjang tahun 2019 tercatat 6,2 juta orang telah berpergian menggunakan moda kereta api dari atau menuju D.I. Yogyakarta dengan peningkatan penumpang sebanyak $7,97 \%$ dari tahun 2018. Banyaknya kunjungan ke Yogyakarta berbanding lurus dengan kebutuhan peningkatan kualitas aksesibilitas transportasi publik. Peningkatan kualitas aksesibilitas transportasi perlu dilakukan pada stasiun kereta api sebagai simpul transportasi moda kereta api. Salah satu stasiun yang terdapat di Kota Yogyakarta adalah Stasiun Yogyakarta.

Peraturan Menteri Perhubungan Nomor PM 98 Tahun 2017 menyatakan bahwa pihak operator transportasi publik harus menyediakan pelayanan bagi penumpang dengan kebutuhan khusus dengan menyediakan sarana dan prasarana layanan yang mudah diakses bagi penumpang berkebutuhan khusus. Penumpang berkebutuhan khusus adalah penumpang difabel dan/atau penumpang dengan 
permintaan khusus yang memerlukan fasilitas dan perlakuan khusus, seperti penyandang disabilitas, lanjut usia, anak-anak, wanita hamil, dan orang sakit (Kementerian Perhubungan, 2017). Salah satu penumpang berkebutuhan khusus adalah penyandang disabilitas. Oleh karena itu, penelitian ini bertujuan untuk mengevaluasi fasilitasfasilitas bagi penyandang disabilitas di Stasiun Yogyakarta sehingga operator kereta api (PT. KAI) dan Pemerintah dapat membuat kebijakan peningkatan kualitas dan kuantitas fasilitas tersebut guna meningkatkan inklusifitas stasiun.

Fasilitas stasiun kereta api bagi penumpang berkebutuhan khusus telah diatur secara umum oleh Kementerian Perhubungan (2017) dalam Peraturan Menteri Perhubungan Nomor PM 98 Tahun 2017 tentang penyediaan aksesibilitas pada pelayanan jasa transportasi publik bagi pengguna jasa berkebutuhan khusus. Berdasarkan peraturan tersebut, disebutkan pada pasal 4 bahwa aksesibilitas bagi pengguna jasa berkebutuhan khusus pada stasiun meliputi ubin tekstur pemandu pada prasarana transportasi, tanda/petunjuk khusus pada area pelayanan yang mudah di akses, informasi visual/audio terkait informasi perjalanan, pintu/gate aksesibel dengan dimensi yang sesuai dengan lebar kursi roda, area menaikkan dan menurunkan penumpang, ramp dengan kemiringan yang sesuai, akses untuk naik turun penumpang yang aksesibel pada bangunan bertingkat, toilet yang aksesibel dengan dimensi pintu toilet yang sesuai dengan lebar kursi roda, loket tiket/counter khusus ticketing yang mudah diakses, ruang tunggu dengan kursi prioritas, ruang menyusui/nursery room dilengkapi dengan fasilitas, poliklinik, ruang bermain anak, tempat parkir, akses bahaya kebakaran, dan ketersediaan kursi roda yang siap pakai.

Penelitian mengenai evaluasi kinerja stasiun sudah pernah dilakukan sebelumnya di Stasiun Yogyakarta oleh Sari (2013), namun penelitian tersebut hanya mengevaluasi kinerja stasiun kereta api berdasarkan Standar Pelayanan Minimum (SPM) yang tertera pada
Peraturan Menteri Perhubungan Nomor PM 9 Tahun 2011. Aspek evaluasi hanya dilakukan pada fasilitas-fasilitas umum stasiun dan fasilitas ramp bagi penyandang disabilitas, bukan fasilitas-fasilitas khusus bagi penyandang disabilitas berdasarkan Peraturan Menteri Perhubungan Nomor PM 98 Tahun 2017 sebagaimana evaluasi yang dilakukan pada penelitian ini. Selain itu, metode pengambilan data pada penelitian tersebut dilakukan melalui observasi dan kuisioner dan hasil penelitian hanya disajikan secara deskriptif kuantitatif.

Metode lain yang pernah dilakukan dalam mengevaluasi stasiun dilakukan oleh Jannah dkk. (2019). Penelitian tersebut mengevaluasi 15 (lima belas) stasiun commuter line yang ada di Jabodetabek dengan cara mengukur tingkat efisiensi masing-masing stasiun berdasarkan luas peron, jumlah gate elektronik, jumlah pegawai, jumlah loket/ mesin tiket, jumlah ATM, jumlah bisnis, dan jumlah penumpang. Metode yang digunakan adalah metode Data Envelopment Analysis (DEA) dan lebih cocok digunakan untuk membandingkan banyak unit dengan jenis/karakteristik yang sama.

Selain evaluasi terhadap simpul transportasi moda kereta api, penelitian terhadap simpul transportasi lainnya juga telah dilakukan. Widiyanto (2019) telah melakukan evaluasi terhadap kinerja pelayanan eksisting pada Pelabuhan Sunda Kelapa serta Juniawan dkk. (2018) telah melakukan evaluasi terhadap Bandara Banyuwangi. Kedua penelitian tersebut melakukan evaluasi untuk simpul transportasi moda laut dan udara menggunakan metode IPA (Importance Performance Analysis). Hal ini menunjukkan bahwa metode IPA merupakan metode yang tepat untuk mengevaluasi kinerja sebuah simpul transportasi sebagaimana metode yang digunakan pada penelitian ini.

Penelitian mengenai inklusifitas Stasiun Yogyakarta telah dilakukan oleh Wicaksono dkk. (2019) serta Mahardika dan Nurhayati (2018). Wicaksono dkk. (2019) melakukan penelitian mengenai pelayanan umum kereta 
api bagi penyandang disabilitas di Stasiun Yogyakarta. Namun pada penelitian tersebut metode yang digunakan adalah metode kualitatif dengan metode pengambilan data berupa wawancara kepada 5 (lima) orang dari pihak manajemen DAOP 6 PT. KAI (Persero) dan 4 (empat) orang pengguna stasiun yang juga merupakan penyandang disabilitas. Penelitian tersebut juga lebih berfokus kepada permasalahan hukum dan kebijakan publik yang berlaku. Mahardika dan Nurhayati (2018) mengusulkan perbaikan sistem aksesibilitas publik bagi penyandang disabilitas dengan pendekatan dinamika sistem (industrial) pada Stasiun Yogyakarta. Penelitian tersebut bertujuan untuk mengetahui hasil causal loop diagram dan stock flow diagram menggunakan bantuan perangkat lunak powersim, Hasil simulasi dinamika sistem dapat digunakan untuk merekomendasikan solusi perbaikan sistem di Stasiun Yogyakarta yang dapat meningkatkan kepuasan pelayanan bagi para penyandang disabilitas.

Berdasarkan penelitian-penelitian tentang evaluasi stasiun dan inklusifitasnya, dapat disimpulkan bahwa penelitian yang diteliti pada naskah ini adalah penelitian dengan lokasi yang sama dengan penelitian sebelumnya (Stasiun Yogyakarta), namun dilakukan melalui pendekatan yang berbeda. Perbedaan tersebut adalah perbedaan aspek/parameter evaluasi dimana pada penelitian ini evaluasi dilakukan berdasarkan Peraturan Menteri Perhubungan Nomor PM 98 Tahun 2017. Selain itu, evaluasi yang dilakukan pada penelitian ini menggunakan metode IPA yang belum pernah diterapkan pada Stasiun Yogyakarta, meskipun penggunaan metode IPA sudah lazim dilakukan sehingga metode ini dapat dianggap tepat untuk melakukan evaluasi terhadap Stasiun Yogyakarta.

\section{METODE PENELITIAN}

Penelitian ini adalah penelitian kuantitatif dengan penggunaan metode IPA (Importance
Performance Analysis) sebagai dasar analisis. Data penelitian diperoleh melalui observasi langsung di Stasiun Yogyakarta dan pengisian kuisioner tingkat kepuasan dan tingkat pelayanan fasilitas khusus bagi penyandang disabilitas yang dilakukan dilakukan pada Tahun 2019.

Observasi langsung dilakukan untuk mengetahui ketersediaan fasilitas-fasilitas bagi penyandang disabilitas yang terdapat di Stasiun Yogyakarta. Data tersebut akan dibandingkan dengan peraturan yang berlaku (Peraturan Menteri Perhubungan Nomor PM 98 Tahun 2017) untuk memverifikasi ketersediaan fasilitas eksisting di Stasiun Yogyakarta.

Pengisian kuisioner dilakukan untuk melakukan evaluasi terhadap fasilitas-fasilitas tersebut berdasarkan tingkat kinerja dan tingkat kepentingannya. Responden pengisian kuisioner adalah penyandang disabilitas yang pernah menggunakan moda transportasi kereta api melalui Stasiun Yogyakarta. Jumlah sampel pengambilan data untuk pengisian kuisioner menggunakan nilai minimum sampel yaitu 30. Hal ini sebagaimana yang dikatakan oleh Cohen dkk. (2007) yaitu semakin besar sampel dari besarnya populasi yang ada adalah semakin baik, akan tetapi ada jumlah batas minimal yang harus diambil oleh peneliti yaitu sebanyak 30 sampel. Pengambilan nilai minimum ini dikarenakan tidak tersedia data akurat mengenai jumlah pengunjung Stasiun Yogyakarta yang juga merupakan penyandang disabilitas.

Terdapat 15 (lima belas) fasilitas khusus bagi penyandang disabilitas yang akan dievaluasi sebagaimana tertera pada Tabel 1. Kelimabelas fasilitas tersebut diadopsi dari Peraturan Menteri Perhubungan Nomor PM 98 Tahun 2017 tentang penyediaan aksesibilitas pada pelayanan jasa transportasi publik bagi pengguna jasa berkebutuhan khusus. 
Kuisioner yang diberikan kepada responden berisi pertanyaan mengenai tingkat kinerja dari 15 (lima belas) fasilitas dengan 5 (lima) pilihan jawaban untuk setiap fasilitasnya yaitu sangat baik, baik, kurang baik, tidak baik, dan sangat tidak baik. Selain itu, terdapat pula pertanyaan mengenai tingkat kepentingan dari 15 (lima belas) fasilitas dengan 5 (lima) pilihan jawaban untuk setiap fasilitasnya yaitu sangat penting, penting, kurang penting, tidak penting, dan sangat tidak penting. Sebelum dianalisis, data hasil kuisioner diuji validitas dan realibilitasnya terlebih dahulu. Menurut Siregar (2013), uji validitas dibutuhkan pada data kuisioner untuk menunjukkan kemampuan kuisioner / alat ukur dalam mengukur apa yang ingin diukur dimana pada penelitian ini digunakan metode uji validitas konstruk dengan bantuan software SPSS. Uji reliabilitas dilakukan untuk mengetahui konsistensi dari hasil pengukuran (Siregar, 2013). Pada penelitian ini digunakan teknik Alpha Croncbach dengan bantuan software SPSS sebagai metode uji reliabilitas.

Tabel 1. Fasilitas yang akan dievaluasi

\begin{tabular}{|c|l|}
\hline No & \multicolumn{1}{|c|}{ Fasilitas } \\
\hline 1 & $\begin{array}{l}\text { Ubin tekstur pemandu (guiding block) pada prasarana } \\
\text { transportasi (pedestrian, loket, toilet dan lain-lain) }\end{array}$ \\
\hline 2 & $\begin{array}{l}\text { Tanda/petunjuk khusus pada area pelayanan yang } \\
\text { mudah di akses (parkir, loket, toilet dan lain-lain) }\end{array}$ \\
\hline 3 & $\begin{array}{l}\text { Informasi visual/audio terkait informasi perjalanan } \\
\text { (berupa tanda-tanda khusus, bunyi dan gambar- } \\
\text { gambar serta huruf Braille pada tempat khusus) }\end{array}$ \\
\hline 4 & $\begin{array}{l}\text { Pintu/gate aksesibel dengan dimensi yang sesuai } \\
\text { dengan lebar kursi roda }\end{array}$ \\
\hline 5 & $\begin{array}{l}\text { Area menaikkan dan menurunkan penumpang (drop } \\
\text { zone) }\end{array}$ \\
\hline 6 & Ramp dengan kemiringan yang sesuai \\
\hline 7 & $\begin{array}{l}\text { Akses untuk naik turun penumpang yang aksesibel } \\
\text { pada bangunan bertingkat }\end{array}$ \\
\hline 8 & $\begin{array}{l}\text { Toilet yang aksesibel dengan dimensi pintu toilet } \\
\text { yang sesuai dengan lebar kursi roda }\end{array}$ \\
\hline 9 & $\begin{array}{l}\text { Loket tiket/counter khusus ticketing yang mudah } \\
\text { diakses }\end{array}$ \\
\hline 10 & Ruang tunggu dengan kursi prioritas \\
\hline 11 & Poliklinik \\
\hline 12 & Tempat parkir \\
\hline 13 & Akses bahaya kebakaran \\
\hline 14 & Ketersediaan kursi roda yang siap pakai \\
\hline 15 & Ruang pusat informasi \\
\hline
\end{tabular}

Data pada penelitian ini dianalisis menggunakan metode IPA (Importance Performance Analysis). Berdasarkan Widiyanto (2019), Importance Performance
Analysis (IPA) merupakan metode analisis untuk mengetahui perbandingan kinerja atau pelayanan suatu jasa yang diterima oleh konsumen atau pengguna jasa dengan tingkat kepuasan yang diinginkan. Pada penelitian ini, kinerja atau pelayanan yang dimaksud adalah kinerja dan pelayanan dari fasilitasfasilitas bagi penyandang disabilitas di Stasiun Yogyakarta, sedangkan konsumen atau pengguna jasa adalah penumpang disabilitas. Faktor pelayanan ini mencakup pendapat penumpang disabilitas mengenai tingkat kepuasan kinerja dari fasilitas stasiun serta tingkat kepentingan fasilitas tersebut Perhitungan menggunakan metode IPA dimulai dari perhitungan tingkat kesesuaian antara kinerja pelaksanaan fasilitas dengan tingkat kepentingan fasilitas yang dirasakan responden kemudian dicari skor rata-rata tingkat kinerja dan tingkat kepentingan. Perhitungan dapat dilihat pada Persamaan 1. dan Persamaan 2.

$T k i=\frac{X i}{Y i} \times 100 \%$

dengan,

$T k i$ : tingkat kesesuaian responden

$X i$ : skor penilaian kinerja fasilitas stasiun

$Y i$ : skor penilaian kepentingan fasilitas stasiun

$\bar{X}=\frac{X i}{n}, \bar{Y}=\frac{Y i}{n}$

dengan,

$\bar{X}$ : skor rata-rata tingkat kinerja fasilitas stasiun

$\bar{Y}$ : skor rata-rata tingkat kepentingan fasilitas stasiun

$n:$ jumlah responden

Kemudian dicari nilai rata-rata perhitungan berdasarkan atribut penilaian. Nilai pada ratarata tingkat kinerja dinyatakan dalam $\overline{\bar{X}}$ sedangkan rata-rata tingkat kepentingan dinyatakan dalam $\overline{\bar{Y}}$. Kedua nilai tersebut dapat dicari dengan menggunakan Persamaan 3.

$\overline{\bar{X}}=\frac{\sum_{i=1}^{n} \bar{X}}{K}, \overline{\bar{Y}}=\frac{\sum_{i=1}^{n} \bar{Y}}{K}$ 
dengan,

$\overline{\bar{X}}$ : nilai rata-rata tingkat kinerja

$\overline{\bar{Y}}$ : nilai rata-rata tingkat kepentingan

$K$ : jumlah atribut penilaian

Setelah data dianalisis menggunakan metode IPA, didapatkan hasil analisis yang direpresentasikan dalam grafik 4 kuadran (Pertahankan Prestasi, Prioritas Rendah, Prioritas Utama, dan Berlebihan) sehingga dapat diambil prioritas peningkatan pelayanan fasilitas-fasilitas bagi penyandang disabilitas di Stasiun Yogyakarta.

\section{HASIL DAN PEMBAHASAN}

\section{Kesesuaian Kondisi Eksisting dengan Peraturan yang Berlaku}

Berdasarkan Peraturan Menteri Perhubungan Nomor PM 98 Tahun 2017 tentang penyediaan aksesibilitas pada pelayanan jasa transportasi publik bagi pengguna jasa berkebutuhan khusus, terdapat beberapa fasilitas yang perlu disediakan di stasiun guna mempermudah aksesibilitas pengguna stasiun berkebutuhan khusus di stasiun. Fasilitasfasilitas tersebut kemudian diambil yang merupakan fasilitas bagi penyandang disabilitas saja sejumlah 15 (lima belas) fasilitas sesuai yang tertulis pada Tabel 1 . Dari hasil observasi langsung, didapatkan bahwa secara umum hampir semua fasilitas telah tersedia di Stasiun Yogyakarta. Namun demikian, terdapat beberapa fasilitas yang belum tersedia yaitu guide block menuju loket dan toilet, informasi dalam huruf Braille pada tempat khusus, loket tiket/counter khusus ticketing dan ruang informasi/ customer service yang mudah diakses. Rekapitulasi ketersediaan fasilitas dapat dilihat pada Tabel 2. Lima belas fasilitas yang diadopsi dari peraturan tersebut juga digunakan sebagai parameter/atribut evaluasi dan selanjutnya akan dievaluasi menggunakan metode IPA (Importance Performance Analysis).

\section{Profil Responden Penelitian}

Data penelitian diperoleh melalui pengisian kuisioner oleh 35 responden penyandang disabilitas yang pernah mengunjungi Stasiun Yogyakarta.

Tabel 2. Rekapitulasi ketersediaan fasilitas pada Stasiun Yogyakarta

\begin{tabular}{|l|l|l|}
\hline No. & \multicolumn{1}{|c|}{ Fasilitas } & \multicolumn{1}{|c|}{ Ketersediaan } \\
\hline 1 & $\begin{array}{l}\text { Ubin tekstur pemandu (guiding block) pada prasarana transportasi } \\
\text { (pedestrian, loket, toilet dan lain-lain) }\end{array}$ & $\begin{array}{l}\text { Sudah tersedia pada pedestrian, namun belum } \\
\text { tersedia pada loket dan toilet }\end{array}$ \\
\hline 2 & $\begin{array}{l}\text { Tanda/petunjuk khusus pada area pelayanan yang mudah di akses } \\
\text { (parkir, loket, toilet dan lain-lain) }\end{array}$ & Sudah tersedia \\
\hline 3 & $\begin{array}{l}\text { Informasi visual/audio terkait informasi perjalanan (berupa tanda- } \\
\text { tanda khusus, bunyi dan gambar-gambar serta huruf Braille pada } \\
\text { tempat khusus) }\end{array}$ & $\begin{array}{l}\text { Sudah tersedia, namun belum tersedia dalam } \\
\text { huruf Braille pada tempat khusus }\end{array}$ \\
\hline 4 & $\begin{array}{l}\text { Pintu/gate aksesibel dengan dimensi yang sesuai dengan lebar kursi } \\
\text { roda }\end{array}$ & Sudah tersedia \\
\hline 5 & Area menaikkan dan menurunkan penumpang (drop zone) & Sudah tersedia \\
\hline 6 & Ramp dengan kemiringan yang sesuai & Sudah tersedia \\
\hline 7 & $\begin{array}{l}\text { Akses untuk naik turun penumpang yang aksesibel pada bangunan } \\
\text { bertingkat }\end{array}$ & $\begin{array}{l}\text { Sudah tersedia ramp, namun masih cukup sulit } \\
\text { diakses }\end{array}$ \\
\hline 8 & $\begin{array}{l}\text { Toilet yang aksesibel dengan dimensi pintu toilet yang sesuai } \\
\text { dengan lebar kursi roda }\end{array}$ & Sudah tersedia \\
\hline 9 & Loket tiket/counter khusus ticketing yang mudah diakses & Sudah tersedia \\
\hline 10 & Ruang tunggu dengan kursi prioritas & Sudah tersedia \\
\hline 11 & Poliklinik & Sudah tersedia \\
\hline 12 & Tempat parkir & Sudah tersedia \\
\hline 13 & Akses bahaya kebakaran & Sudah tersedia \\
\hline 14 & Ketersediaan kursi roda yang siap pakai & Sudah tersedia \\
\hline 15 & Ruang pusat informasi & Sudah tersedia \\
\hline
\end{tabular}


Pengisian kuisioner dilakukan untuk mengukur tingkat kepuasan dan kepentingan fasilitas penyandang disabilitas di Stasiun Yogyakarta. Hasil survei tersebut kemudian diolah menggunakan metode Importance Performance Analysis (IPA) sehingga dapat diperoleh evaluasi fasilitas bagi penyandang disabilitas dan prioritas peningkatan fasilitas tersebut. Data responden penelitian dapat dilihat pada Gambar 1.

Berdasarkan Gambar 1, dapat diketahui bahwa mayoritas responden berjenis kelamin laki-laki (63\%), memiliki jenis disabilitas fisik (67\%), memiliki penghasilan kurang dari sama dengan Rp 500.000,00 (46\%), frekuensi menaiki kereta 1-3 kali (64\%), tujuan perjalanan adalah jarak jauh ke arah Barat (60\%), berusia 20-30 tahun (43\%), berdomisili di Sleman (37\%), dan terakhir kali menaiki kereta lebih dari 1 tahun yang lalu (53\%). Namun demikian, meskipun 53\% responden menaiki kereta terakhir kali lebih dari 1 tahun yang lalu, dalam kuisioner telah diberikan gambar-gambar fasilitas stasiun terbaru sehingga responden dapat memberikan nilai kepuasan dengan lebih tepat dan sesuai.

\section{Rekapitulasi Tingkat Kinerja dan Tingkat Kepentingan}

Berdasarkan kuisioner yang telah diisi oleh responden, didapatkan tingkat kinerja dan tingkat kepentingan dari 15 (lima belas) fasilitas bagi penyandang disabilitas di Stasiun Yogyakarta. Rekapitulasi tingkat kinerja dan tingkat kepentingan fasilitas dapat dilihat pada Tabel 3 dan Tabel 4. Angkaangka yang tertera pada kedua tabel tersebut adalah jumlah responden yang memilih masing-masing pilihan tingkat kinerja dan tingkat kepentingan fasilitas stasiun.

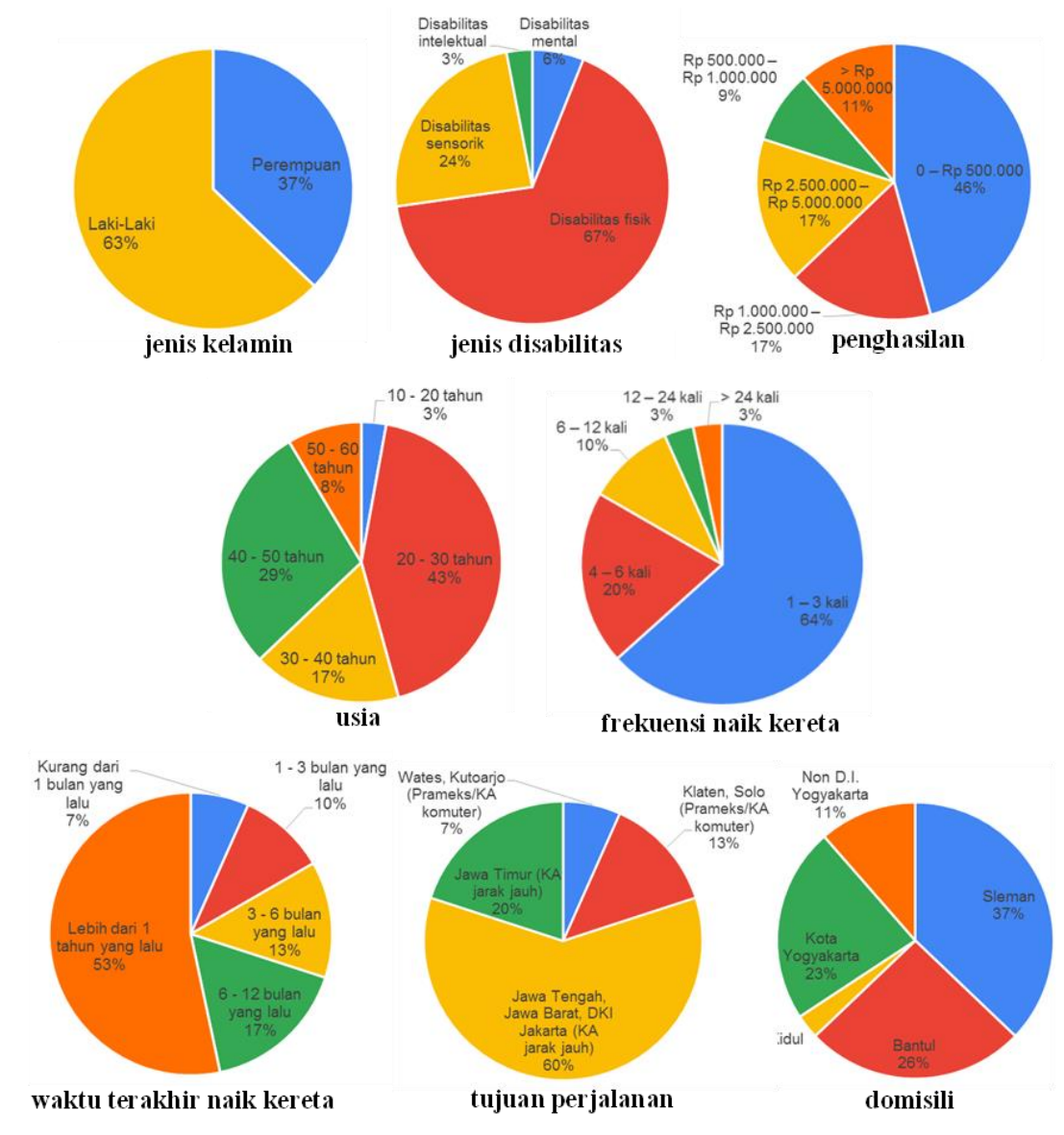

Gambar 1. Profil responden penelitian 
Tabel 3. Rekapitulasi tingkat kinerja fasilitas stasiun menurut responden

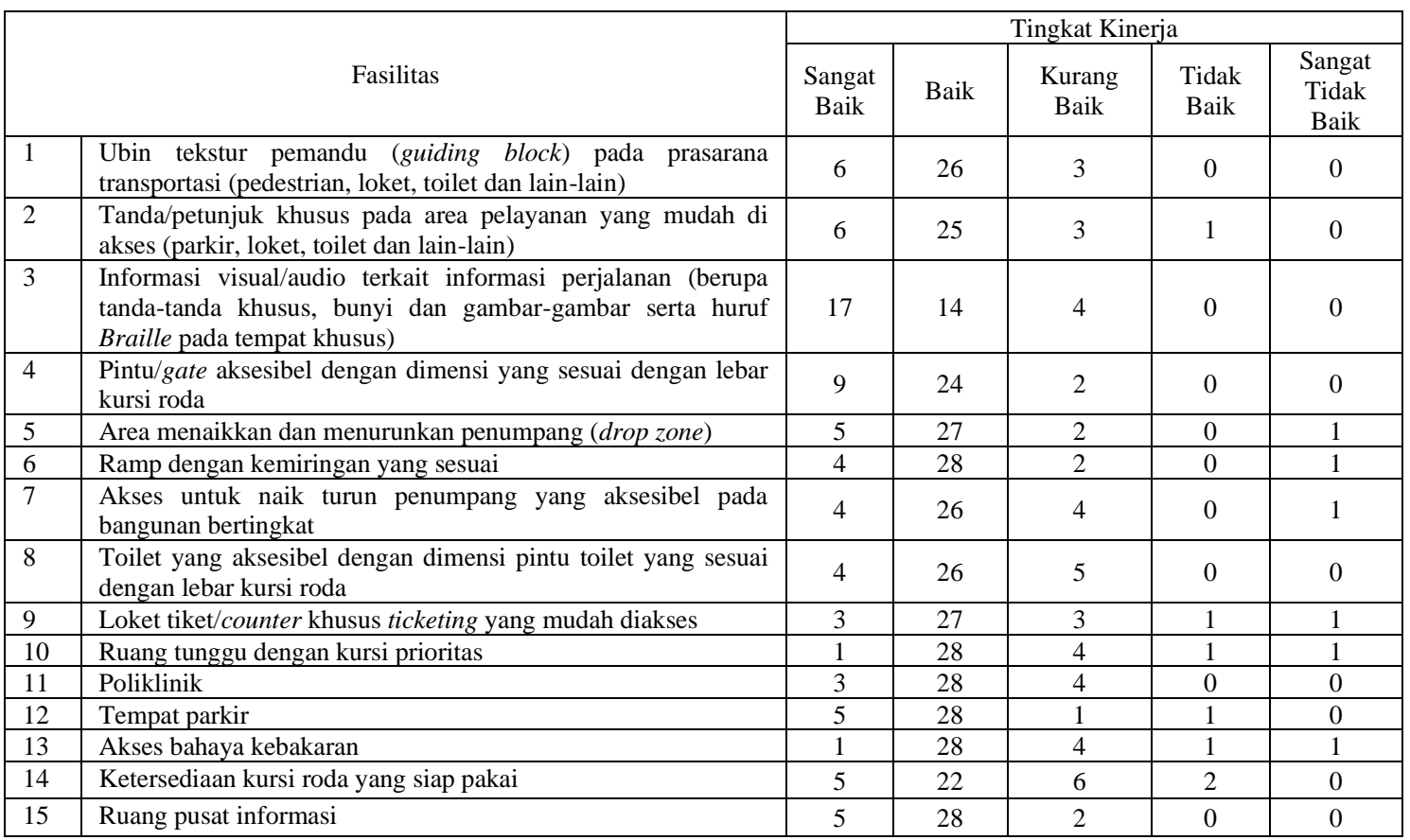

Tabel 4. Rekapitulasi tingkat kepentingan fasilitas stasiun menurut responden

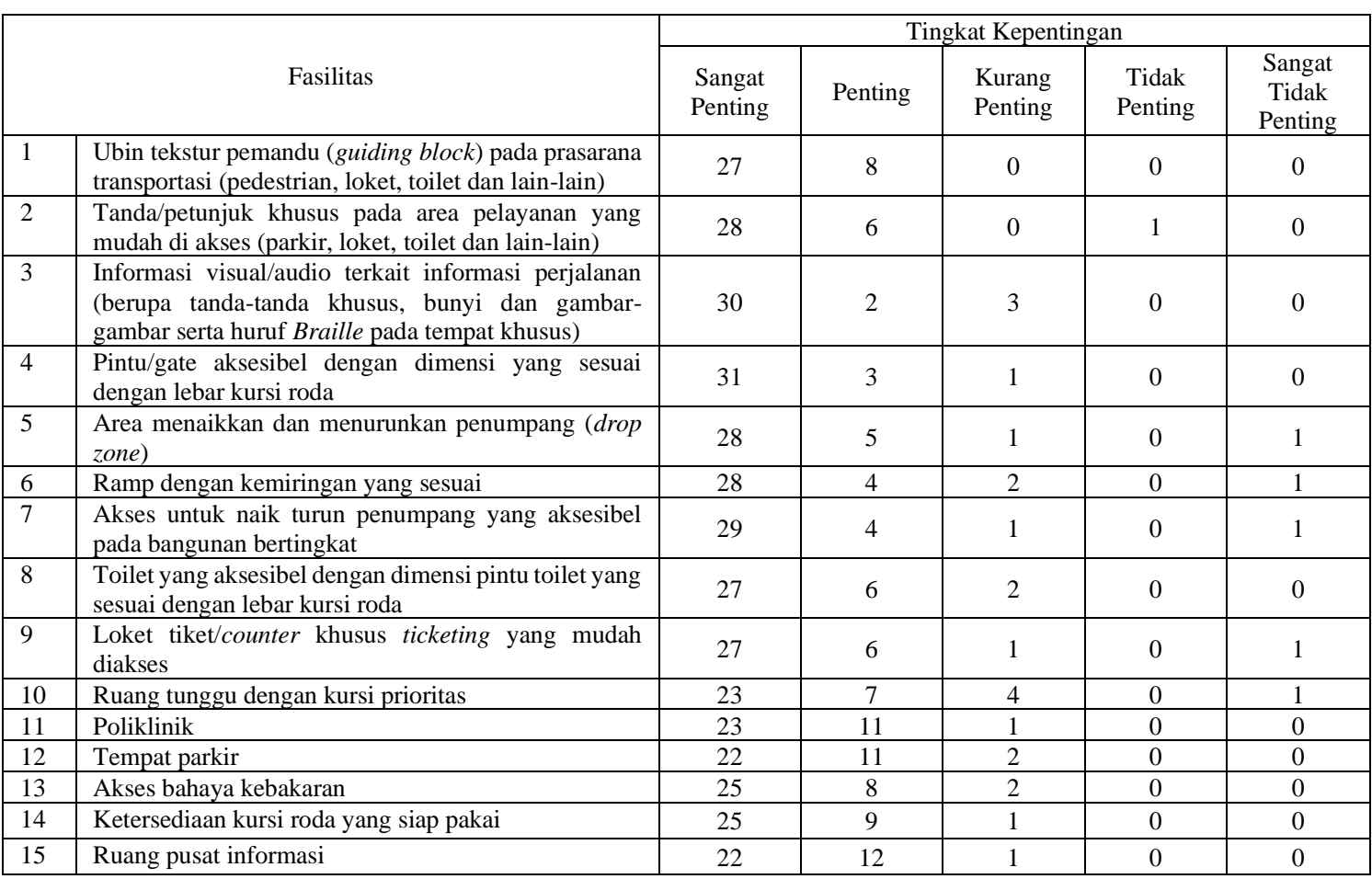




\section{Uji Validitas dan Uji Reliabilitas}

Metode validitas konstruk digunakan untuk melakukan proses validasi dalam penelitian ini. Metode validitas konstruk adalah suatu metode validasi yang bertujuan untuk mengetahui kesanggupan suatu alat ukur dalam mengukur suatu konsep yang diukurnya. Nilai $\alpha$ dan $r_{\text {tabel }}$ yang digunakan pada penelitian ini adalah 0,05 dan 0,334. Nilai $r_{\text {tabel }}$ kemudian dibandingkan dengan $\mathrm{r}_{\text {hitung }}$ dari masing-masing kelompok pertanyaan (15 pertanyaaan tentang fasilitas stasiun). Nilai $r_{\text {hitung didapatkan melalui }}$ software SPSS dan didapatkan bahwa nilai $\mathrm{r}_{\text {hitung }}$ dari masing-masing kelompok pertanyaan telah melebihi nilai $r_{\text {tabel }}$. Hal ini memberikan kesimpulan bahwa kuesioner yang digunakan pada penelitian ini dapat digunakan dan data yang didapat melalui survei kuesioner adalah valid.

Teknik Alpha Croncbach digunakan pada penelitian ini untuk melakukan uji reliabilitas terhadap hasil pengukuran. Pada uji reliabilitas ini dibantu pula dengan software SPSS. Berdasarkan hasil perhitungan didapatkan bahwa nilai koefisien reliabilitas untuk hasil kuisioner tingkat kinerja adalah 0,826 dan untuk hasil kuisioner tingkat kepentingan adalah 0,931 Kedua nilai koefisien reliabilitas tersebut lebih dari 0,6 dan dapat dinyatakan bahwa bahwa kuesioner dapat digunakan dan data yang didapat melalui survei kuesioner adalah reliable. Data yang reliabel menunjukkan bahwa pengukuran yang dilakukan dapat dipercaya (Yusup, 2018). Selain itu, reliabilitas data juga menenjukkan bahwa hasil pengukuran adalah konsisten (Siregar, 2013).

\section{Analisis Menggunakan Metode IPA (Importance Performance Analysis)}

Setelah dilakukan uji validitas dan uji reliabilitas, data yang didapatkan melalui kuisioner selanjutnya diolah dan dianalisis menggunakan metode IPA (Importance Performance Analysis). Hasil pengukuran untuk 15 (lima belas) fasilitas yang dievaluasi dapat dilihat melalui Tabel 5.

Hasil pengukuran menggunakan metode IPA direpresentasikan dalam bentuk diagram kartesiuss yang memiliki 4 kuadran yaitu A, B, C, dan D (Widiyanto, 2019). Setiap jenis fasilitas akan berada pada salah satu dari keempat kuadran tersebut. Fasilitas yang berada pada kuadran A adalah fasilitas yang dianggap sangat penting namun pihak manajemen stasiun belum melaksanakan sesuai keinginan pengguna stasiun, kuadran B menunjukkan bahwa fasilitas tersebut sudah memenuhi ekspektasi pengguna stasiun dan wajib dipertahankan kinerjanya, kuadran $\mathrm{C}$ adalah fasilitas yang dirasa kurang penting bagi pengguna stasiun dan pihak manajemen stasiun juga menyediakan kinerja fasilitas yang biasa-biasa saja, sedangkan kuadran D adalah fasilitas yang dirasa kurang penting bagi pengguna stasiun namun kinerjanya terlalu berlebihan.

Diagram kartesius yang menunjukkan kuadran 15 (lima belas) fasilitas untuk penyandang disabilitas yang berada di Stasiun Yogyakarta dapat dilihat pada Gambar 2. Berdasarkan Gambar 2 diketahui bahwa fasilitas yang terletak pada kuadran A (prioritas utama) adalah ketersediaan kursi roda yang siap pakai, akses untuk naik turun penumpang yang aksesibel pada bangunan bertingkat, serta toilet yang aksesibel dengan dimensi pintu toilet yang sesuai dengan lebar kursi roda. Fasilitas yang terletak pada kuadran B (pertahankan prestasi) adalah area menaikkan dan menurunkan penumpang (drop zone), tanda/petunjuk khusus pada area pelayanan yang mudah di akses (parkir, loket, toilet dan lain-lain), ubin tekstur pemandu (guiding block) pada prasarana transportasi (pedestrian, loket, toilet dan lain-lain), pintu/gate aksesibel dengan dimensi yang sesuai dengan lebar kursi roda, dan informasi visual/audio terkait informasi perjalanan (berupa tanda-tanda khusus, bunyi dan gambar-gambar serta huruf Braille pada tempat khusus). 
Tabel 5. Perhitungan atribut pengukuran Stasiun Yogyakarta

\begin{tabular}{|c|c|c|c|c|c|}
\hline Fasilitas & $\begin{array}{l}\text { Penilaian Tingkat Kinerja } \\
\text { (Xi) }\end{array}$ & $\begin{array}{l}\text { Penilaian Tingkat } \\
\text { Kepentingan (Yi) }\end{array}$ & Tki & $\bar{X}$ & $\bar{Y}$ \\
\hline 1 & 143 & 167 & $85,63 \%$ & 4.09 & 4.77 \\
\hline 2 & 141 & 166 & $84,94 \%$ & 4.03 & 4.74 \\
\hline 3 & 153 & 167 & $91,62 \%$ & 4,37 & 4,77 \\
\hline 4 & 147 & 170 & $86,47 \%$ & 4,20 & 4,86 \\
\hline 5 & 140 & 164 & $85,37 \%$ & 4,00 & 4,69 \\
\hline 6 & 139 & 163 & $85,28 \%$ & 3,97 & 4,66 \\
\hline 7 & 137 & 165 & $83,03 \%$ & 3,91 & 4,71 \\
\hline 8 & 139 & 165 & $84,24 \%$ & 3,97 & 4,71 \\
\hline 9 & 135 & 163 & $82,82 \%$ & 3,86 & 4,66 \\
\hline 10 & 132 & 156 & $84,62 \%$ & 3,77 & 4,46 \\
\hline 11 & 139 & 162 & $85,80 \%$ & 3,97 & 4,63 \\
\hline 12 & 142 & 160 & $88,75 \%$ & 4,06 & 4,57 \\
\hline 13 & 132 & 163 & $80,98 \%$ & 3,77 & 4,66 \\
\hline 14 & 135 & 164 & $82,32 \%$ & 3,86 & 4,69 \\
\hline 15 & 143 & 161 & $88,82 \%$ & 4,09 & 4,60 \\
\hline Total & 2097 & 2456 & - & 59,91 & 70,17 \\
\hline \multirow{2}{*}{\multicolumn{3}{|c|}{ Nilai Rata-Rata }} & $\overline{\bar{X}}$ & 3,99 & - \\
\hline & & & $\overline{\bar{Y}}$ & - & 4,68 \\
\hline
\end{tabular}

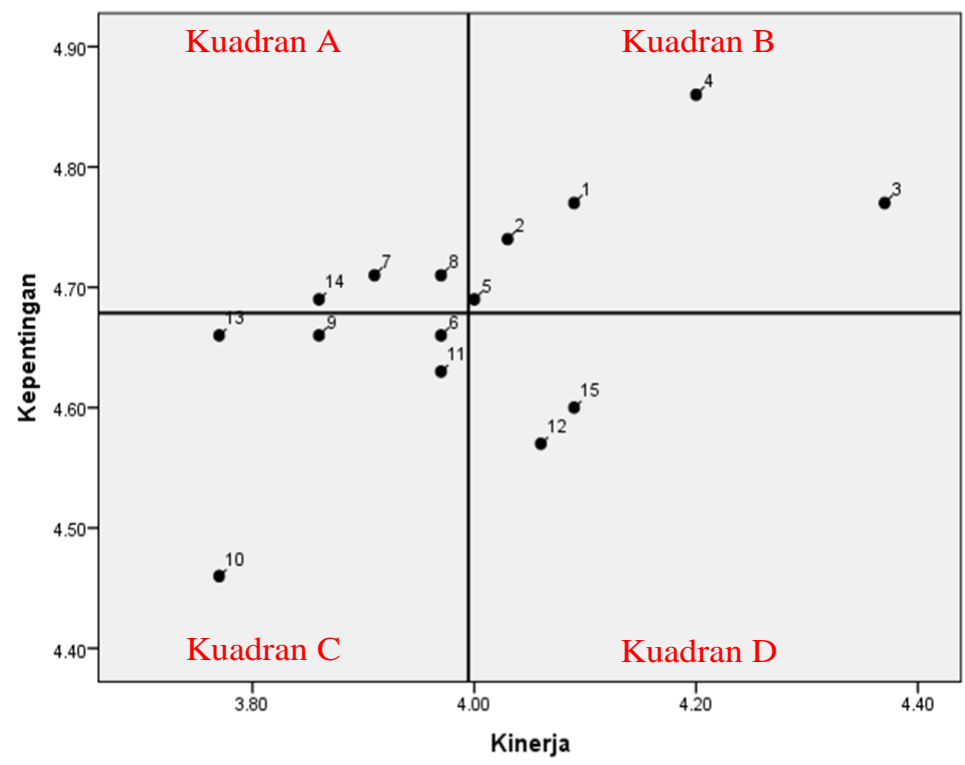

Gambar 2. Diagram kartesius 15 fasilitas bagi penyandang disabilitas di Stasiun Yogyakarta

Fasilitas yang terletak pada kuadran C (prioritas rendah) adalah ruang tunggu dengan kursi prioritas, akses bahaya kebakaran, loket tiket/counter khusus ticketing yang mudah diakses, poliklinik, dan ramp dengan kemiringan yang sesuai. Terakhir, fasilitas yang berada pada kuadran D (berlebihan) adalah tempat parkir dan ruang pusat informasi. Rekapitulasi hasil evaluasi bagi 15 (lima belas) fasilitas dapat dilihat pada Tabel 6. 
Tabel 6. Rekapitulasi hasil evaluasi fasilitas bagi penyandang disabilitas di Stasiun Yogyakarta

\begin{tabular}{|l|l|c|}
\hline \multicolumn{1}{|c|}{ Fasilitas } & Hasil Evaluasi \\
\hline 1 & $\begin{array}{l}\text { Ubin tekstur pemandu (guiding block) pada prasarana transportasi (pedestrian, loket, toilet } \\
\text { dan lain-lain) }\end{array}$ & Pertahankan Prestasi \\
\hline 2 & $\begin{array}{l}\text { Tanda/petunjuk khusus pada area pelayanan yang mudah di akses (parkir, loket, toilet dan } \\
\text { lain-lain) }\end{array}$ & Pertahankan Prestasi \\
\hline 3 & $\begin{array}{l}\text { Informasi visual/audio terkait informasi perjalanan (berupa tanda-tanda khusus, bunyi dan } \\
\text { gambar-gambar serta huruf Braille pada tempat khusus) }\end{array}$ & Pertahankan Prestasi \\
\hline 4 & Pintu/gate aksesibel dengan dimensi yang sesuai dengan lebar kursi roda & Pertahankan Prestasi \\
\hline 5 & Area menaikkan dan menurunkan penumpang (drop zone) & Pertahankan Prestasi \\
\hline 6 & Ramp dengan kemiringan yang sesuai & Prioritas Rendah \\
\hline 7 & Akses untuk naik turun penumpang yang aksesibel pada bangunan bertingkat & Prioritas Utama \\
\hline 8 & Toilet yang aksesibel dengan dimensi pintu toilet yang sesuai dengan lebar kursi roda & Prioritas Utama \\
\hline 9 & Loket tiket/counter khusus ticketing yang mudah diakses & Prioritas Rendah \\
\hline 10 & Ruang tunggu dengan kursi prioritas & Prioritas Rendah \\
\hline 11 & Poliklinik & Prioritas Rendah \\
\hline 12 & Tempat parkir & Berlebihan \\
\hline 13 & Akses bahaya kebakaran & Prioritas Rendah \\
\hline 14 & Ketersediaan kursi roda yang siap pakai & Prioritas Utama \\
\hline 15 & Ruang pusat informasi & Berlebihan \\
\hline
\end{tabular}

\section{Pembahasan}

Berdasarkan analisis dengan menggunakan metode IPA yang ditunjukkan oleh Gambar 2 dan Tabel 6, didapatkan bahwa fasilitas yang berada pada kuadran A (prioritas utama) adalah fasilitas yang dirasa penting bagi penyandang disabilitas, namun kinerja pelayanannya secara kuantitas dan kualitas masih dirasa kurang. Oleh karena itu, seluruh fasilitas yang berada pada kuadran A diharapkan dapat menjadi prioritas dalam rangka peningkatan fasilitas oleh pihak manajemen Stasiun Yogyakarta.

Prioritas peningkatan yang pertama adalah pada penyediaan kursi roda yang mudah dijangkau penyandang disabilitas dengan jumlah yang memadai. Terkait dengan fasilitas ini sebetulnya telah tersedia kursi roda yang siap pakai, namun informasi dan tanda bahwa tersedia kursi roda perlu dibuat lebih jelas lagi (diletakkan di dekat drop zone) dan lokasi kursi roda siap pakai juga diletakkan di dekat drop zone. Kedua, melakukan peningkatan kualitas akses untuk naik turun penumpang yang aksesibel pada bangunan bertingkat. Terkait fasilitas ini sebetulnya sudah tersedia ramp menuju bangunan bertingkat (menuju loket dan ruang informasi/ customer service) namun apabila fasilitas ini bisa ditingkatkan maka kinerja pelayanannya akan lebih baik mengingat cukup pentingnya loket dan ruang informasi/ customer service (misalnya dengan menambahkan lift tangga khusus kursi roda). Ketiga, melebarkan dimensi pintu dan akses menuju toilet disabilitas yang sudah ada sehingga memudahkan akses penyandang disabilitas yang menggunakan kursi roda.

Tahapan selanjutnya setelah fasilitas yang diprioritaskan selesai ditingkatkan, peningkatan fasilitas Stasiun Yogyakarta dapat ditujukan pada peningkatan kondisi ruang tunggu dengan kursi prioritas, penyediaan akses bahaya kebakaran yang mudah dilihat dan dipahami oleh pengguna jasa, penyediaan loket khusus ticketing yang mudah diakses, poliklinik yang memadai dan mudah di akses, serta penyediaan petugas khusus yang membantu penyandang disabilitas jika menemui kesulitan di dalam Stasiun Yogyakarta.

Hasil yang didapatkan pada penelitian ini serupa dengan penelitian Sari (2013) yang menyatakan bahwa diperlukan peningkatan dan perbaikan pada lantai beralur (guiding block). Pada penelitian ini dinyatakan bahwa lantai beralur (guiding block) merupakan salah satu fasilitas yang perlu dipertahankan kinerjanya karena sudah cukup baik secara umum meskipun diperlukan peningkatan pada fasilitas lantai beralur menuju loket dan toilet dikarenakan saat ini belum tersedia. 
Penelitian Wicaksono dkk. (2019) yang dilakukan dengan metode kualitatif (wawancara) menyatakan bahwa fasilitas informasi visual/audio terkait informasi perjalanan sudah tersedia, namun terdapat penumpang tunarungu yang belum mengetahui ketersediaan fasilitas ini. Selain itu, informasi mengenai mekanisme bantuan terhadap penumpang difabel yang disediakan oleh petugas stasiun belum tersebar dengan baik sehingga terdapat penumpang difabel yang belum mengetahui informasi penting tersebut serta ketidakpekaan petugas juga merupakan hal yang perlu diperbaiki oleh manajemen Stasiun Yogyakarta berdasarkan penelitian tersebut. Jika dibandingkan dengan hasil penelitian ini, terdapat beberapa hasil yang berbeda dikarenakan penelitian Wicaksono dkk. (2019) mengevaluasi pelayanan umum bagi penyandang disabilitas baik fasilitas maupun pelayanan petugas secara kualitatif, sedangkan penelitian ini berfokus pada evaluasi fasilitasnya saja secara kuantitatif. Namun demikian, hasil penelitian tersebut dapat dikombinasikan dengan penelitian ini dimana perihal tersebarnya informasi mengenai ketersediaan fasilitas bagi penyandang disabilitas di Stasiun Yogyakarta merupakan hal yang dapat menunjang kinerja fasilitas tersebut.

Salah satu usaha yang dapat dilakukan untuk menyebarkan informasi terkait ketersediaan fasilitas bagi penyandang disabilitas di Stasiun Yogyakarta adalah sosialisasi kepada lembaga atau komunitas difabel secara masif serta penyebaran informasi melalui media sosial yang dapat dilihat oleh pendamping penyandang disabilitas. Hal ini sesuai dengan amanat yang tertera pada pasal 106 UndangUndang Nomor 8 Tahun 2018 tentang penyandang disabilitas bahwa Pemerintah dan Pemerintah Daerah wajib menyebarluaskan dan menyosialisasikan pelayanan publik yang mudah diakses kepada penyandang disabilitas dan masyarakat. Penyebaran informasi ini diharapkan dapat meningkatkan persepsi penumpang difabel terhadap kinerja pelayanan fasilitas bagi penyandang disabilitas di Stasiun Yogyakarta.

\section{KESIMPULAN}

Kondisi eksisting fasilitas-fasilitas bagi penyandang disabilitas pada Stasiun Yogyakarta secara umum sudah tersedia sesuai dengan Peraturan Menteri Perhubungan Nomor PM 98 Tahun 2017, Namun terdapat beberapa fasilitas yang belum terpenuhi yaitu guide block menuju loket dan toilet, informasi dalam huruf Braille pada tempat khusus, loket tiket/counter khusus ticketing dan ruang informasi/ customer service yang mudah diakses.

Prioritas peningkatan fasilitas bagi penyandang disabilitas pada Stasiun Yogyakarta yang didapatkan melalui metode IPA (Importance Performance Analysis) dilakukan terhadap fasilitas yang masuk kedalam kuadran A pada digram kartesius yaitu penyediaan kursi roda yang mudah dijangkau penyandang disabilitas dengan jumlah yang memadai, melakukan peningkatan kualitas akses untuk naik turun penumpang yang aksesibel pada bangunan bertingkat, dan melebarkan dimensi pintu dan akses menuju toilet disabilitas yang sudah ada sehingga memudahkan akses penyandang disabilitas yang menggunakan kursi roda.

\section{UCAPAN TERIMA KASIH}

Ucapan terima kasih ditujukan kepada Direktorat Penelitian dan Pengabdian Masyarakat (DPPM) Universitas Islam Indonesia atas Hibah Penelitian DPPM UII dengan skema Penelitian Pemula berdasarkan surat perjanjian pelaksanaan penelitian nomor 01/Dir/DPPM/70/Pen.Pemula/III/2020.

\section{DAFTAR PUSTAKA}

Badan Pusat Statistik Provinsi DI Yogyakarta. (2017). "Provinsi DI Yogyakarta dalam Angka Tahun 2017". Daerah Istimewa Yogyakarta. 
Cohen, L., Manion, L., \& Morrison, K. (2007). "Research Methods in Education (6th Edition)". Routllege Falmer.

Jannah, A. N., Muthohar, I. \& Parikesit, D. (2020). "Efficiency Analysis of Commuter Line Stations (Case Study: Tebet Station to Cilebut Station, Indonesia)". Proceeding of the $2^{\text {nd }}$ International Symposium on Transportation Studies in Developing Countries (ISTSDC 2019), Kendari, Sulawesi Tenggara, Indonesia, November 1-3, Vol.193.

Juniawan, D. M., Wicaksono, A., \& Kusumaningrum, R. (2018). "Kajian Kinerja Pelayanan Sisi Darat Bandara Banyuwangi dengan Metode IPA dan SWOT". Tesis. Universitas Brawijaya.

Mahardika, S. W., \& Nurhayati, E. (2018). "Usulan Perbaikan Sistem Aksesibilitas Publik bagi Penyandang Disabilitas dengan Pendekatan Dinamika Sistem (Studi Kasus di Stasiun Yogyakarta)". IEJST (Industrial Engineering Journal of The University of Sarjanawiyata Tamansiswa), Vol. 2, No. 2, 113-124.

Kementerian Perhubungan. (2017). "Peraturan Menteri Perhubungan Nomor PM 98 Tahun 2017 Tentang Penyediaan Aksesibilitas pada Pelayanan Jasa Transportasi Publik Bagi Pengguna Jasa Berkebutuhan Khusus". Jakarta.

Sari, R. R. (2013). "Evaluasi Kinerja Stasiun Kereta Api Berdasarkan Standar Pelayanan Minimum (SPM)". Industrial Research Workshop and National Seminar (IRWNS), Vol. 4, 6570.

Siregar, S. (2013). "Statistik Parametrik Untuk Penelitian Kuantitatif Dilengkapi Dengan Perhitungan Manual dan Aplikasi SPSS Versi 17”. Bumi Aksara.

Republik Indonesia. (2007). "UndangUndang Republik Indonesia Nomor 23
Tahun 2007 Tentang Perkeretaapian”. Jakarta.

Republik Indonesia. (2018). "UndangUndang Nomor 8 Tahun 2018 Tentang Penyandang Disabilitas". Jakarta.

Wicaksono, T. T., Pradana, G. H. \& Simamora, J. I. G. (2019). "Pelayanan Umum Kereta Api di Yogyakarta". INKLUSI: Journal of Disability Studies, Vol. 6, No. 1, 47-70.

Widiyanto, Y. A. (2019), “Evaluasi Fasilitas Eksisting Pelabuhan dan Rencana Pengembangan Pelabuhan Sunda Kelapa”. Tesis. Universitas Gadjah Mada.

Yosep, Febrianawati. (2018). "Uji Validitas Dan Reliabilitas Instrumen Penelitian Kuantitatif". Jurnal Tarbiyah: Jurnal Ilmiah Kependidikan, Vol. 7, No. 1, 1723. 